is more purely academic-will realize that absolute assurance as to facts in field evidence is essential. Less than absolute assurance may be interesting but is economically useless.

Dr. Harker and I, from our respective experiences in various parts of the world, obviously take different points of view, and therefore I suppose must agree to differ upon this problem of the Sgùrr of Eigg.

The Dutch House, Beaconsfield.

E. H. Cunningham-Craig. March 1, 1920 .

[The foregoing letter was submitted to Dr. Harker in MS.; his reply is printed below.-ED. GEoL. MaG.]

SIR,-I am sorry if the tone of my former note on this subject was unsuitable. It is no doubt a Don's failing to dislike being patronized, even by an old student.

I should not trouble you again were it not that Mr. CunninghamCraig persists in representing that I stand for "theory " while he is the champion of "field evidence". I must point out once more that my theory was the same as his until I came to survey the ground, when the field evidence compelled me to a different interpretation. There was no question of "microscopic petrology" until Mr. Craig introduced it, when he claimed to decide that the granite fragments in the Eigg agglomerate are of a Tertiary, not a Palæozoic type. It seems that, despite his compliments, he will not allow me the same privilege in respect of the granite fragments in Skye and elsewhere. His experience in many parts of the world may be, like Sam Weller's knowledge of London, extensive and peculiar, but does not seem to have much bearing upon this specific point.

Alfred Harker.

\title{
PALEONTOLOGICAL ABSTRACTS.
}

Sir,-Probably most of your readers are by this time aware that the Société Géologique de Belgique has undertaken to publish a "Review of Geology and Connected Sciences", consisting of summaries of recent papers written, so far as possible, by the authors themselves. Further information may be obtained from the Secretary to the Review, Laboratoire de Géologie, Université de Liége.

The object of this letter is to inform British Palæontologists that the new Review, instead of competing with La Revue critique de Paléozoologie, which M. Cossmann has been bravely conducting for over twenty years, will take it into collaboration, leaving the direction in the hands of M. Cossmann. All writers on Palæozoology in this country are therefore asked to be good enough to send M. Maurice Cossmann, 110 Faubourg Poissonière, Paris, Xe., separate copies of their papers, or if that be impossible, at least the title and bibliographic details of each publication.

F. A. BAther. 